Anna Miller-Klejsa

Uniwersytet Łódzki

Instytut Romanistyki/Zakład Italianistyki

https://doi.org/10.18778/8220-478-0.13

\title{
ZŁODZIEJE ROWERÓW NA TRASIE W-Z UWAGI O RECEPCJI DZIEŁA DE SIKI W POLSKIM PIŚMIENNICTWIE FILMOWYM DO 1956 ROKU
}

Streszczenie: Po zakończeniu II wojny światowej kultura filmowa w Polsce Ludowej uległa istotnej transformacji. Jednym z jej aspektów był nowy model importu filmów: większość międzynarodowych źródeł została zastąpiona filmami z komunistycznego bloku, głównie z ZSRR. Filmy włoskie stanowily w tych realiach istotny wyjątek: publiczność polska była zaznajomiona nie tylko z filmami, ale także - dzięki przekładom publikowanym w prasie branżowej - $\mathrm{z}$ teoretycznymi tezami nurtu C. Zavattiniego i U. Barbaro (ten ostatni w latach 1948-1949 wykładał nawet w lódzkiej Szkole Filmowej). Niektóre filmy uznawane za neorealistyczne nie zostały jednak dopuszczone na polskie ekrany przez cenzurę (zakazano m.in. wyświetlania kilku filmów Rosselliniego), lub pojawiły się w kinach ze znaczącym opóźnieniem (los taki spotkał m.in. film Umberto D.).

W artykule koncentruję się na zbadaniu recepcji filmu Złodzieje rowerów (Ladri dibiciclette, reż. V. De Sica, 1948) w polskim czasopiśmiennictwie filmowym lat 1946-1956. Analiza wykazała, że o ile w latach 1946-1949 przeważają raczej pozytywne głosy, o tyle od początku lat 50., w okresie stalinizacji, dominują głosy krytyczne; odkąd ideałem stało się kino radzieckie i poetyka socrealizmu, włoski neorealizm (i film De Siki) oskarżany był o pesymizm oraz gubienie "wielkich perspektyw rewolucyjnych". To podejście uległo zmianie $\mathrm{w}$ czasie odwilży, kiedy neorealizm stał się swoistym wzorem do naśladowania - przykładem nowatorskiej estetyki filmowej.

Słowa kluczowe: kino włoskie, neorealizm, recepcja filmu

Abstract: After 1945 and with the onset of the Cold War, the cinema culture in People's Republic of Poland underwent rigorous transformation. One of its aspects was the new movie import schema: most of international sources dried up to be replaced, for the most part, by films from the Communist bloc, principally the Soviet Union. Italian movies constituted an important exception: Polish audience became 
acquainted not only with several Italian films labelled as neorealist but also - thanks to translations published in the trade press - with theoretical works of C. Zavattini and U. Barbaro (the latter was even appointed as professor at the Film School in Lodz). However, some movies associated with neorealism were either not allowed by the censorship bodies (it banned several Rossellini's works) or appeared on Polish screens with significant delay (which was the case of Umberto D.)

In the article I focus on the reception on Bicycle Thieves (Ladri di biciclette, dir. V. De Sica, 1948) in the Polish movie magazines and books published between 1946 and 1956. The analysis showed that during the first post-war years the positive reviews were prevailing. However, in the early 1950s - in the period of Stalinization in Poland - critical opinions became predominant. Since the Soviet social realism was treated as the ideal, the Italian neorealism (and the De Sica's film) was accused of pessimism and losing sight of "great revolutionary perspectives". This attitude changed during the Thaw when neorealism became more or less accepted as a positive example of progressive aesthetic.

Keywords: Italian cinema, neorealism, film reception research

Złodzieje rowerów Vittoria De Siki - obsypane deszczem nagród zarówno we Włoszech (sześć „Srebrnych taśm”/Nastro d'argento), jak i poza granicami Italii (Oscar dla najlepszego filmu nieanglojęzycznego, nagroda specjalna na festiwalu w Locarno, Złoty Glob, nagroda BAFTA) to realizacja wymieniana w wielu zestawieniach „najlepszych filmów świata”. Przykładowo, w 1952 roku dzieło to zajęło trzecie miejsce (za Pancernikiem Potiomkinem Siergieja Eisensteina i Gorączka Złota Charliego Chaplina) w plebiscycie na najlepszy film od czasów narodzin X Muzy ${ }^{1}$. Fabuła De Siki znajduje się także na liście 100 film italiani da salvare (100 filmów włoskich do ocalenia), utworzonej w 2008 roku podczas Festiwalu Filmowego w Wenecji ${ }^{2}$. Film ten już w momencie premiery został doceniony przez zagraniczną krytykę. Na pokazie w Paryżu zorganizowanym dla ponad trzytysięcznej widowni De Sica odebrał gratulacje od René Claire’a i André Gide’a, a brytyjski „Sight and Sound” nazwał Złodziei rowerów arcydziełem ${ }^{3}$. We Włoszech film również spotkał się z aprobatą rodzimej krytyki. Co prawda Złodzieje rowerów odniosły umiarkowany sukces wśród włoskiej publiczności - zajęły bowiem 11 miejsce w krajowym box

1 Plebiscyt został zorganizowany przez dyrekcję brukselskiego festiwalu filmowego. Osoby profesjonalnie zajmujące się filmem miały podać listę 10 najlepszych filmów z lat 1895-1952.

2 Lista miała na celu wskazanie 100 włoskich filmów, które wpłynęły na pamięć zbiorową Włoch w latach 1942-1978 (ankietę wypełniały wtedy osoby profesjonalnie zajmujące się kinem).

3 R. Winnington, Bicycle Thieves, „Sight and Sound” 1950, 19, s. 26. 
offisie - ale biorąc pod uwagę los innych neorealistycznych produkcji wynik ten należy uznać za wyróżniający (dla porównania film Niemcy - rok zerowy Roberta Rosselliniego w sezonie 1948/1949 uplasowal się na czterdziestym szóstym, a Ziemia drży Luchina Viscontiego - na pięćdziesiątym drugim miejscu ${ }^{4}$ ). Świadectwem tego, że realizacja De Siki wpisała się w historię światowego kina i nieustannie porusza kolejne pokolenia widzów pozostają wreszcie liczne doń nawiązania w filmach innych reżyserów (zob. m.in. Złodzieje mydetek Maurizia Nichettiego; Byliśmy tacy zakochani Ettora Scoli; Wspomnienia z gwiezdnego pytu Woody'ego Allena; Gracz Roberta Altmana) oraz ich niezwykle pochlebne opinie na temat dzieła De Siki. Gianni Amelio - jeden z najczęściej nagradzanych twórców włoskiego kina lat 90. - stwierdził:

[...] przeżyłem wiele miłości filmowych, ale jako dojrzały reżyser zostałem przy De Sice. Jeśli miałbym wskazać epizod, który, w moim przekonaniu, zawiera sens kina; kina, które chciałbym zrobić i mam nadzieję realizować, to wskazałbym finał Złodziei rowerów. Zakończenie Złodziei rowerów to właśnie to, czego oczekuję od kina jako widz i jako reżyser5.

W niniejszym tekście chciałabym podjąć temat recepcji Złodziei rowerów w polskim czasopiśmiennictwie filmowym do 1956 roku. Recepcja dzieła De Siki, które weszło na ekrany polskich kin, cztery lata po włoskiej premierze, w 1951 roku (a zatem w czasie zaostrzonej sowietyzacji życia publicznego i kulturalnego, o czym będzie jeszcze mowa), skupia bowiem jak w soczewce zmiany w ocenie nurtu neorealistycznego, która dokonała się na przestrzeni kilku lat i była uzależniona od sytuacji politycznej w Polsce. Trzeba przy tym od razu zaznaczyć, że kinematografia włoska w Polsce Ludowej, a szczególnie filmy włoskiego neorealizmu, były traktowane dość ulgowo w stosunku do dzieł kinematografii innych krajów kapitalistycznych. Przyczyniły się do tego zapewne komunistyczne sympatie wielu neorealistycznych reżyserów, a także - wynikający zresztą z tych właśnie okoliczności - fakt, że w latach 1948-1949 w łódzkiej Szkole Filmowej wykładali Umberto Barbaro (włoski krytyk, teoretyk, także tłumacz wielu książek z zakresu teorii filmu) i Aldo Vergano (ten ostatni wraz z Tadeuszem Kańskim zrealizował film Czarci żleb w 1949 roku). Polscy widzowie mieli więc okazję poznać szereg neorealistycznych filmów (w sumie w latach 1946-1956 na ekranach polskich kin wyświetlono ponad

4 Neorealistycznym przebojem był z pewnością film Rzym, miasto otwarte, który zajął 1. miejsce wśród innych włoskich produkcji w sezonie 1945/1946. Dobre wyniki uzyskał też film $W$ imieniu prawa - 3. miejsce w krajowym box offisie w sezonie 1948/1949 oraz Gorzki ryż - 5. miejsce w sezonie 1949/1950. Informację podaję za: P. Noto, F. Pitassio, Il cinema neorealista, Bologna 2012, s. 166.

5 E. Martini (red.), Gianni Amelio: le regole e il gioco, Bergamo 1999, s. 132. 
20 neorealistycznych fabul) oraz - dzięki przekładom publikowanym w prasie branżowej - zaznajomić się z teoretycznymi tezami nurtu ${ }^{6}$.

Polsko-włoskie relacje w latach 1945-1956 ulegały przemianom, których rytm był wyznaczany przede wszystkim przez ksztaltowanie się dwubiegunowego podziału świata, w tym Europy, na zwalczające się bloki polityczno-militarne. O ile jeszcze w latach 1945-1947 wymiana gospodarcza pomiędzy państwami położonymi po obu stronach tworzącej się żelaznej kurtyny wydawała się realna (choć ograniczona w skali), o tyle już od 1948 roku stawała się niemal niemożliwa w obliczu umacniania się atmosfery zimnowojennej. Od 1948 roku, po utworzeniu PZPR, komuniści całkowicie zdominowali życie polityczne w Polsce. Równocześnie rozpoczęli gwałtowną indoktrynację połączoną z przejmowaniem kontroli nad kolejnymi segmentami życia publicznego, czemu towarzyszyło rozbudowanie cenzury prewencyjnej. Sytuacja ta zaczęła nieco się zmieniać po 1953 roku w miarę narastania procesów destalinizacyjnych, ale na prawdziwy przełom trzeba było jeszcze poczekać.

Podobnym fluktuacjom podlegała polityka kulturalna, w tym dystrybucja filmów zagranicznych w Polsce. Można pokusić się zatem o wyróżnienie trzech głównych okresów recepcji włoskiego nurtu ściśle związanej z polityką repertuarową: 1946-1949; 1949-1954; 1954-1956. Ten pierwszy okres trwający od jesieni 1946 (gdy w dystrybucji pojawily się pierwsze legalnie zakupione filmy zagraniczne) do połowy 1949 roku to czas, gdy w kinach wyświetlano sporą liczbę filmów z krajów kapitalistycznych, w tym wiele produkcji hollywoodzkich. Od III kwartału 1949 roku filmy z Europy Zachodniej są wycofywane z ekranów, zaś w latach 1950-1954 repertuar kinowy w Polsce budowany jest już głównie w oparciu o filmy krajów demokracji ludowej

Pierwsze wzmianki o Ztodziejach rowerów pojawily się na łamach czasopisma „Film” w 1949 roku (trzy lata przed polską premierą filmu), a zatem w momencie tzw. zwrotu stalinizacyjnego, którego symbolicznym znakiem stał się zorganizowany wówczas Zjazd w Wiśle. Zjazd ten przypieczętował państwowy nadzór nad kinematografią, uprawomocnił dyktat ideologii socjalizmu realistycznego. Miał też uświadomić artystom konieczność wcielania w życie teorii

6 Warto zauważyć, że wśród filmów dopuszczonych na polskie ekrany nie było neorealistycznych filmów Roberta Rosselliniego ( $\mathrm{z}$ wyjątkiem Rzymu, miasta otwartego). Polscy widzowie nie mogli zatem obejrzeć ani filmu Paisa ani Niemcy - rok zerowy; Stromboli, ziemia Boga, Franciszek, kuglarz boży; zabrakło także filmów z Ingrid Bergman. Niektóre filmy włoskie trafiały zaś na polskie ekrany ze sporym opóźnieniem - np. zrealizowany w 1951 roku film Umberto D. doczekał się polskiej premiery w 1957 roku, a Vivere in pace nakręcony w 1946 roku był wyświetlany w Polsce 10 lat później.

7 Więcej na ten temat zob. K. Klejsa, Świat, który przezwyciężamy i pozostawiamy za soba. Import, rozpowszechnianie i widownia filmowa $z$ krajów kapitalistycznych $w$ Polsce Ludowej w latach 1949-1956 w świetle badań archiwalnych, „Kwartalnik Filmowy” 2019, 108. 
Żdanowa przez uczestnictwo $\mathrm{w}$ walce klasowej, z równoczesnym potępieniem tzw. odchyleń prawicowo-nacjonalistycznych ${ }^{8}$. Ów „Zwrot stalinizacyjny” w kinematografii rzutowal, jak wspomniałam, na całą kulturę filmową - nie tylko na produkcję, ale także na politykę repertuarową, w tym na ocenę zagranicznych fabul. Od tej pory niedoścignionym wzorem pozostaje kino radzieckie, co dobrze unaocznia opublikowany w połowie 1949 roku krótki tekst na temat włoskiej kinematografii, w której pojawia się tytuł omawianego dzieła De Siki:

Realizatorzy włoscy [...] obrazują przede wszystkim walkę o lepsze jutro i czynną postawę włoskiej klasy robotniczej, włoskich chłopów i inteligencji pracującej. [...] Inna rzecz, że zdrowsze moralnie filmy radzieckie kładą większy nacisk na pozytywne strony życia, dają większe pole do popisu bohaterom dodatnim niż wstecznym i reakcyjnym siłom działającym z ukrycia. Włochy mają jednak dzisiaj jedyną na zachodzie ciekawą pod względem treści kinematografię, czego dowodzą takie filmy jak Złodzieje rowerów, Ziemia drży, w Imieniu prawa ${ }^{9}$.

Zamieszczona w innym numerze „Filmu” relacja z międzynarodowego festiwalu w Belgii, na którym Złodzieje rowerów zdobyły pierwszą nagrodę, potwierdza ówczesne zaostrzenie antyamerykańskiej retoryki. Karolina Beylin pisze tak:

[...] tematem jest upadek moralny człowieka $\mathrm{w}$ ustroju kapitalistycznym, a treścią po prostu pogoń naklejacza afiszów za skradzionym mu rowerem, dekoracją - ulice miasta, gdzie pracują, bawią się cierpią i radują się zwykli powszedni ludzie - nie "gwiazdy" płaczące woskowymi łzami w blasku jupiterów nad zboczeniami córek miliarderów i popełnionymi w imię dolara zbrodniami ${ }^{10}$.

We wcześniejszym numerze tego samego czasopisma podkreślono zaś, że De Sica nie zgodził się na powierzenie głównej roli Cary’emu Grantowi, jednak zamiast hollywoodzkiej gwiazdy reżyser wybrał "naturszczyka”, robotnika z rzymskiej huty żelaza - Lamberta Maggioraniego ${ }^{11}$.

8 Na Zjeździe zjawiło się kilkaset osób - nie tylko filmowców, ale także pisarzy oraz działaczy partyjnych. Oceny polskiej kinematografii dokonali Jerzy Albrecht (kierownik Wydziału Propagandy, Oświaty i Kultury KC PZPR) oraz Włodzimierz Sokorski (wiceminister kultury i sztuki). Uczestnicy zjazdu obejrzeli także przedpremierowo Czarci żleb T. Kańskiego i A. Vergano. Więcej o zjeździe zob. P. Zwierzchowski, Pęknięty monolit, Bydgoszcz 2005, s. 193-194.

9 „Film” 1949 nr 17, s. 15 (odpowiedź na list czytelniczki).

10 K. Beylin, Doświadczenia, które ucza ..., „Film” 1949, 16, s. 15.

11 J. Płażewski, Robotnik z huty Breda, „Film” 1949, 15, s. 12. To oczywiście fakty - za decyzją De Siki nie stała jednak motywacja polityczna, jak sugerowano w polskim czasopiśmie; nie jest nawet pewne, czy reżyser zrezygnował z aktora ze względu 
Rok 1950 jest szczególny - w całym roczniku „Filmu” znajdują się jedynie cztery wzmianki o włoskim neorealizmie i żadna z nich nie dotyczy konkretnego filmu; być może dlatego, że to rok, w którym nie wprowadzono na polskie ekrany żadnej włoskiej produkcji. Podane informacje są natomiast bardzo wybiórcze, a w swej selektywności upolitycznione. Jedną z nich jest wypowiedź Lamberta Maggioraniego dla radzieckiej gazety. Antonio z dzieła De Siki mówi o tym, że został zwolniony z pracy po wystąpieniu w filmie Złodzieje rowerów, a przecież „gdyby we Włoszech panował socjalizm, mógłby rozwinąć swe aktorskie zdolności i stać się dobrym aktorem zawodowym" ${ }^{12}$. Informacja ta jest opatrzona właściwym dla lat stalinizacji komentarzem: „Czytelników radzieckich wywody Maggioraniego nie dziwią. Jego przyszłość w ZSRR tak by się zapewne ułożyła. Przykro aż myśleć, jak kapitalizm degraduje człowieka; jak spycha w błoto ludzi, którzy powinni przodować swoim społeczeństwem”"13.

na emploi gwiazdora, które nie pasowało do tematu filmu. Wedle niektórych źródeł De Sica długo bowiem negocjował z przedstawicielami Davida O. Selznicka warunki ewentualnego kontraktu, próbując przekonać ich do zastąpienia Granta Henrym Fondą, jednak wysłannicy amerykańskiej wytwórni zrazili go naciskami na dokonanie zmian w scenariuszu (np. sceny finałowej, gdyż - ich zdaniem - amerykańska publiczność nie zaakceptowałaby widoku gwiazdora policzkowanego i obrażanego przez tłum) oraz na podpisanie kontraktu na wylączność aż na siedem lat. Współpracę z Amerykanami storpedowała zatem najprawdopodobniej niezgoda De Siki na ograniczenie własnej autonomii jako reżysera. Zob. E. Baldini, Ladri di biciclette e l'America, [w:] De Santi Gualtiero (red.), Ladri di biciclette. Nuove ricerche e un'antologia della critica (1948-1949), Laceno 2009, s. 63. Roy Armes wspomina nawet o pomyśle zrealizowania filmu w potrójnej wersji językowej z Jeanem Gabinem w wersji francuskiej. Zob. R. Armes, Patterns of Realism. A Study of Italian Neo- Realist Cinema, London 1971, s. 142.

12 L. Tałow, A we Wloszech? Gtos Protestu „Film” 1952, 44, s. 5 (przedruk z „Sowietskoje Iskusstwo").

13 To nie do końca prawda - Maggiorani faktycznie stracił pracę, ale nie dlatego, że zagrał u De Siki, tylko z powodu bankructwa huty Breda, w której pracował w rok po premierze filmu. Oprócz wcielenia się w Antonia Ricci, największym osiągnięciem Maggioraniego była rola antyfaszystowskiego robotnika Marca w filmie Carla Lizzaniego Achtung! Banditi! (1951). Ponadto pojawil się w takich filmach jak Umberto D. (Vittorio De Sica, 1952), Don Camillo e l'onorevole Peppone (Carmine Gallone, 1955), Mamma Roma (Pier Paolo Pasolini, 1962). W 1952 roku Cesare Zavattini wpadł nawet na pomysł scenariusza zatytułowanego Tu, Maggiorani (Ty, Maggiorani), opowiadającego o losie aktora. "Jest on zmęczony i zagubiony. Przechodzi koło kina, gdzie wyświetlają Złodziei rowerów. Nie chcą go wpuścić, choć zagrał głównego bohatera. W końcu Maggiorani wchodzi i ogląda film. Wzruszony seansem, stoi w thumie ludzi, którzy nie zwracają na niego uwagi. Wszyscy wychodzą z kina, podnoszą kołnierze plaszczy i udają się do swoich cieplych domów, zapominając szybko o tym, co zobaczyli”. Jednak 
W okresie 1951-1953, a zatem w apogeum stalinizmu, do dystrybucji w Polsce nie trafił żaden film amerykański, a obrazów z innych krajów kapitalistycznych było bardzo niewiele. W 1951 roku na polskie ekrany wprowadzono dwa filmy włoskie: Złodziei rowerów oraz Ziemia drży ${ }^{14}$. Można zatem powiedzieć, że dzieło De Siki w czasie stalinizmu zostało niejako wyróżnione. Przypuszczenie, że projekcja Złodziei rowerów stanowiła ważne wydarzenie (przynajmniej dla środowiska filmowego) potwierdza czwarty numer czasopisma „Film” z 1951 roku. Na jego okładce widnieje bowiem kadr z filmu (prezentujący Antonia i Bruna), zaś wewnątrz numeru zamieszczono obszerne omówienie fabuły opatrzone fotosami, a także, oddzielnie, recenzję dzieła. Ta ostatnia jest symptomatyczna dla omawianego okresu - zawiera bowiem szereg zarzutów wobec neorealistycznego filmu, choć zarazem Ztodzieje rowerów zostają w niej nazwani „wybitną pozycją kinematografii włoskiej”; chwalone są także "plastyczne" zdjęcia oraz kreacje aktorskie. Recenzent stwierdza jednak:

[...] $\mathrm{w}$ tym ponurym obrazie rzeczywistości, ukazanym $\mathrm{w}$ przekrojach ostrych, nabrzmiałych treścią, wyjawiających prawdę niezawinionej krzywdy mas ludzkich i beznadziejny los człowieka dotkniętego śmiertelną chorobą ustroju kapitalistycznego, bezrobociem, zabrakło całkowicie jakiejkolwiek nuty pozytywnej, jaśniejszej barwy, motywu nadziei. [...] Film jest udanym atakiem na stosunki społeczne i na warunkujące je podstawy ustrojowe [...] ale nie ukazuje żadnej drogi przełamania tego stanu rzeczy. A moment pozytywny mógłby wynikać z tematu i treści filmu najprościej i najprawdziwiej. Jest nim przecież siła organizacyjna świata robotniczego. Tej siły zbiorowej, montującej elementy zwycięstwa w przyszłości nie pokazali realizatorzy zupełnie. Dlatego film pozostawia wrażenie pesymistyczne ${ }^{15}$.

żaden reżyser (z De Siką włącznie) nie podjął się przeniesienia na ekran owej gorzkiej historii. Cyt. za: Orio Caldiron, 1948, nasce un capolavoro, [w] Ladri di biciclette. Nuove ricerche..., s. 19. O pomyśle szerzej pisze Anita Bielańska w rozprawie Między spektaklem a rzeczywistością. Twórczość filmowa Vittoria De Siki w latach 1940-1960 (nieopublikowana praca doktorska napisana pod kierunkiem prof. Alicji Helman), s. 148.

14 Wśród innych przejawów ówczesnej współpracy polsko-włoskiej w dziedzinie kinematografii wskazać można otrzymywanie włoskich czasopism filmowych (przekazywanych Przedsiębiorstwu Państwowemu Film Polski). W „rewanżu” przesłano do włoskiej encyklopedii artykuł Jerzego Toeplitza o polskim filmie. W zimnowojennej atmosferze trudno było doprowadzić do szerszej współpracy. Obostrzenia cenzuralne utrudniały nie tylko rozpowszechnianie filmów włoskich w Polsce, lecz także polskich we Włoszech. Zob. m.in. AMSZ z. 8, t. 290, w. 22. O zakazie wyświetlania we Włoszech Ostatniego etapu, w reżyserii Wandy Jakubowskiej zob. AMSZ, z. 8, w. 22, t. 290.

15 K. M., Złodzieje oskarżaja swym losem prawdziwych winowajców, „Film” 1951, 4, s. 10. 
Co ciekawe, zarzuty te okazały się wprost odwrotne do zastrzeżeń, które miała wobec filmu włoska cenzura prewencyjna. Wątpliwości wzbudziła bowiem (niezmieniona w ostatecznej wersji filmu) scena politycznego zebrania, w której padają słowa: „Rząd, co nam daje bezrobotnym? Nie powinieneś przyjmować premii, dali ci jałmużnę!” Wedle włoskiego cenzora „kwestie te - szczególnie za granicą - mogły wywołać błędne wrażenie, że pracownicy mają zamiary rewolucyjne"16. Przywołany cytat z polskiej recenzji poświadcza, że dzieło De Siki czytano wyłącznie przez pryzmat doktryny socrealistycznej - zwracając uwagę na słusznie (w rozumieniu ówczesnej ideologii) ukazaną w filmie biedę i „niesłusznie” pominiętą konieczność walki o „lepszy ustrój”. Nie ulega wątpliwości, że był to temat eksponowany wówczas w całej twórczości artystycznej (nie tylko w dziedzinie kinematografii) i „centralnie sterowany”. Przykładowo, w 1953 roku, w salach wystawowych Związku Polskich Artystów Plastyków w Warszawie, zaprezentowana została wystawa grafików włoskich, którzy podejmowali problem robotniczej nędzy. Taką samą tematykę miała wystawa prac Renata Guttusa w Lublinie i Katowicach (wówczas Stalinogrodzie) rok później, na co wskazują same tytuły wystawionych obrazów (m.in. Rodzina bezrobotnego, Żony górników z kopaln siarki ${ }^{17}$.

Jeśli idzie o kinematografię, istotną zmianę przynosi rok 1954. Zapewne nie bez znaczenia pozostaje fakt, że $\mathrm{w}$ tym roku miała miejsce narada filmowa w SPATiFie, która rozpoczęła stopniowe odchodzenie kina polskiego od zasad socrealizmu ${ }^{18}$. Wtedy także zainteresowanie neorealizmem oraz intensywność

16 Materiał Ladri-di-biciclette-Materiale-dellArchivio-Centrale-dello-Stato. pdf; dostępny na stronie: http://cinecensura.com/. Jest to strona projektu „Cinecensura” zrealizowana przez Ministero dei Beni e delle Attività Culturali e del Turismo we współpracy z szeregiem instytucji związanych z kinem. Cytat pochodzący z dokumentu podaję w thumaczeniu własnym. Być może polscy widzowie tego „wywrotowego" potencjału sceny nie dostrzegli, ze względu na listę dialogową, która nie uwzględniała tych kwestii w tłumaczeniu filmu na język polski.

17 Guttuso jako jeden z niewielu artystów włoskich przyjechał do Polski (w styczniu 1954 roku). Zob. AAN, KWKzZ, 271, Sprawozdanie z organizacji wystawy prac Renato Guttusa, Lublin, 11.VI 1954, k.2. Podaję za: M. Pasztor, D. Jarosz, Nie tylko Fiat. Z dziejów stosunków polsko-włoskich 1945-1989, Warszawa 2018, s. 141.

18 Wedle Jerzego Toeplitza, stała się ona "w sferze ideowo-twórczej punktem zwrotnym $\mathrm{w}$ historii polskiej kinematografii” (J. Toeplitz, Historia filmu polskiego tom III, Warszawa 1974, s. 222). Piotr Zwierzchowski lagodzi nieco tę konstatację, stwierdzając, że naradę można uznać za pewien znak zbliżających się przemian. (Zob. P. Zwierzchowski, Pęknięty monolit, s. 195). Sytuację dobrze oddaje nieco poetyckie stwierdzenie Edwarda Zajička, który w swojej książce stwierdza: - „Nadszedł rok 1954. Jeszcze nie czuło się odwilży, ale mróz zelżał”. E. Zajiček, Poza ekranem. Kinematografia polska 1918-1991, Warszawa 1992, s. 133. 
jego recepcji wzrosła - być może był to odprysk kryzysu repertuarowego lat wcześniejszych. Na ekranach polskich kin w roku 1954 wyświetlono sześć włoskich filmów (m.in. Nadziei za dwa grosze, Proces przeciwko miastu oraz Rzym, godzina 11$)^{19}$. W każdym razie od tego roku filmy neorealistyczne - zarówno te dopiero co wprowadzone na polskie ekrany, jak i te wcześniejsze, podlegające reinterpretacji - zaczynają być oceniane w przeważającej mierze pozytywnie. Interesujący nas Ztodzieje rowerów nazwani zostają ,jednym z doskonalszych filmów powojennych" ${ }^{20}$ oraz "filmem wybitnym” przez Krzysztofa T. Toeplitza w obszernym artykule zamieszczonym w „Kwartalniku Filmowym”21. Choć esej nosi tytul: Komentarz do filmu „Rzym, godzina 11”, tekst jest de facto próbą rekapitulacji dokonań całego nurtu neorealistycznego. Co prawda Toeplitz, zgodnie z obowiązującą wówczas wykładnią, przyrównuje neorealizm do tradycji kina radzieckiego („Włosi jednak zaangażowali swoją sztukę po stronie ludu włoskiego, po stronie postępu, biorąc w tym względzie przykład z kinematografii radzieckiej”), ale podkreśla różnorodność włoskiego nurtu („bogactwo odmian, metod ujęć - oto sytuacja w dziedzinie neorealizmu”). Wyróżnia przy tym trzy „główne drogi twórcze” włoskich, neorealistycznych reżyserów: 1. „odejścia od treści postępowych i tematyki społecznej” (jako przykład autor wskazuje dorobek filmowy Roberta Rosselliniego), 2. „wahań i wątpliwości” (tu wymienia De Sikę) oraz 3. „największej konsekwencji ideowej” (sytuuje tu realizacje Viscontiego, Castellaniego i De Santisa). Dokonania reżyserskie De Siki Toeplitz podsumowuje następująco: „Droga De Siki to droga wahań i wątpliwości uczciwego humanisty, który jednak nie zawsze umie bezbłędnie znaleźć ścieżki prowadzące na pozycje konsekwentnie postępowe"22. To istotne spostrzeżenie - humanistyczny wymiar twórczości Włocha - nie zostaje niestety w artykule rozwinięte.

O szczególnej pozycji kina włoskiego w ówczesnej Polsce zaświadcza książka pod tytułem O filmie wtoskim, opublikowana w 1955 roku, autorstwa Stanisława Grzeleckiego i Haliny Laskowskiej, w której główny akcent położony

19 Wśród tych sześciu filmów, które nazwałam włoskimi, były także koprodukcje włosko-francuskie - prócz filmu Rzym, godzina 11 były to: Awantura o dziecko; Złodzieje i policjanci; Tosca. Rok wcześniej w Polsce wyświetlono trzy filmy włoskie: Cud w Mediolanie, Droga nadziei, Najpiękniejsza oraz Fanfan Tulipan (koprodukcja francusko-włoska).

20 K. T. Toeplitz, Groch o ekran, Warszawa 1955, s. 19. Książka to zbiór cotygodniowych felietonów filmowych Toeplitza zamieszczanych od czerwca 1953 roku w „Nowej kulturze”, w cyklu - „W kinie i gdzie indziej”.

21 K. T. Toeplitz, Komentarz do filmu „Rzym godzina 11”, „Kwartalnik Filmowy” 1964, 2. Film w reżyserii Giuseppe De Santisa wszedł na polskie ekrany w 1954 roku i był szeroko komentowany w prasie.

22 Ibidem, s. 31. 
został właśnie na neorealizm. I choć wspomniana praca jest napisana językiem nowomowy (z pozycji marksizmu-leninizmu), zawiera błędy rzeczowe (np. mylnie podano datę założenia Centro Sperimentale w Rzymie) oraz budzi zastrzeżenia związane $\mathrm{z}$ nieco nieporadnie stosowaną terminologią z zakresu estetyki filmu („montaż jest nierówny, często przypadkowy”), stanowi pierwszą próbę zebrania dostępnego materiału w formie większej publikacji. Ma przy tym charakter popularyzatorski, co autorzy sami podkreślali. Realizacji De Siki poświęcono w książce sporo miejsca (niemal siedem stron), a omówienie filmu zostało wyodrębnione graficznie (podtytułem Przeciw samotności). Również i w tym fragmencie publikacji trafiają się przekłamania (np. nazwisko autora literackiego pierwowzoru filmu u Laskowskiej i Grzeleckiego brzmi Bartoglio zamiast Bartolini ${ }^{23}$ ). Najciekawsze - z punktu widzenia recepcji filmu - są jednak wnioski dotyczące zakończenia Złodziei rowerów:

Kiedyś, później, Antonio na pewno zacznie sumować pozbierane doświadczenia. Pobudzona faktami świadomość rozpocznie żmudną pracę oceny i uogólniania. Wnioski zaczną rysować się nieustępliwie. I Antonio spostrzeże, iż zestawia rachunek, pod którym mogą się podpisać miliony towarzyszy ${ }^{24}$

- twierdzą autorzy; zaś kilka stron dalej konstatują: „Antonio Ricci [...] nie podjął walki z przyczynami swojej biedy. Ale wszak - jak ktoś słusznie powiedział - robotnik w filmie nie musi robić rewolucji ze świadomością, że tylko ona zmieni jego los. Natomiast robotnicy patrzący na film - muszą to zrozumieć" ${ }^{25}$. Autorzy książki bronią zatem finałowej sekwencji dzieła, odpierając tym samym zarzuty dotyczące jego rzekomego pesymizmu formułowane kilka lat wcześniej.

Rok 1956 przynosi dalsze ożywienie stosunków polsko-włoskich. W Italii zaktywizowano działalność Stacji Naukowej PAN w Rzymie, zaś w ramach festiwalu filmowego w Wenecji otwarto ekspozycję polskiego plakatu filmowego. Na ekrany polskich kin trafia m.in. zaliczany do neorealizmu film Vivere in pace (po 10 latach od włoskiej premiery). W tym samym roku wydano specjalny numer „Filmu”, w całości poświęcony włoskiemu nurtowi. W kwietniowym wydaniu czasopisma znalazły się teksty Cesare Zavattiniego, Giuseppe De Santisa, Vittoria De Siki oraz rozmowy z Albertem Lattaudą, Luchino Viscontim i Aldem Fabrizim, zaś w artykule wstępnym (zatytułowanym $W$ hotdzie wielkiej sztuce!) tego numeru, Kazimierz Dębnicki (ówczesny redaktor naczelny „Filmu") pisał w superlatywach:

23 S. Grzelecki, H. Laskowska, O filmie włoskim, Warszawa 1955, s. 73.

24 Ibidem, s. 77.

25 Ibidem, s. 80. 
To, że neorealiści nadali piękny kształt artystyczny obrazowi życia, cierpień, miłości, pragnień swego narodu - jest przyczyną ogromnej popularności w naszym kraju. [...] Dla nas krytyków a przede wszystkim dla nas realizatorów - przykład włoski posiada ogromną cenę. [...] Jesteśmy wdzięczni filmowcom włoskim za to co nam w ciągu lat dali: za ich pouczające, odważne eksperymenty, za ich sztukę. [...] Numer „Filmu” ma być skromnym dowodem tego, że prawdziwa, wielka, zrodzona z miłości do człowieka sztuka - nie zna granic. Dociera znad Tybru nad Wisłę ${ }^{26}$.

Począwszy od kwietniowego numeru „Filmu”, w kilku następnych wydaniach czasopisma publikowane są także wspomnienia Vittoria De Siki pod tytułem Moje życie, moje filmy, moje porażki, opatrzone licznymi fotografiami. O szczególnej atencji dla tego reżysera świadczy także okładka 14 numeru „Filmu” - na ostatniej stronie znajduje się bowiem fotos De Siki z jego odręczną dedykacją dla czytelników periodyku oraz krótką notką o Włochu. De Sika nazwany zostaje $\mathrm{w}$ niej ,jednym $\mathrm{z}$ najwybitniejszych filmowców na świecie” i opisany jako „reżyser Złodziei rowerów i Cudu w Mediolanie”. Historia Antonia Ricciego staje się więc znakiem rozpoznawczym sylwetki twórczej Włocha.

W pochwalnym tonie utrzymane są także dwa eseje opublikowane w 1956 roku na łamach „Kwartalnika Filmowego”. Pierwszy, pióra Krzysztofa T. Toeplitza, zawiera ciekawe refleksje na temat obecności dzieci w twórczości włoskiego artysty. Są one wedle Toeplitza świadkiem prezentowanej rzeczywistości oraz jasnym wyznacznikiem dobra i zła („oczy dziecka, sąd moralny dzieci... są dla De Siki obowiązujące również w świecie dorosłych"27). W swoim szkicu Toeplitz wyjaśnia również pojęcie humanizmu utopijnego, którym próbował opisać ścieżkę twórczą De Siki już w 1954 (także na łamach „Kwartalnika Filmowego”, o czym była już mowa). Toeplitz stwierdza, że „humanizm utopijny", który charakteryzuje filmy De Siki to:

program społecznie bierny, w tym znaczeniu, że nie nawołujący do jakiegoś konkretnego rozwiązania społecznych dylematów, a równocześnie niezwykle aktywny społecznie w sensie wrażliwości na krzywdę, jaką rodzi współczesny świat. [... ] I Chaplin, i De Sica uchylają się od światopoglądowego wyboru, ale głos ich podnosi się zawsze, gdy elementarne zasady ludzkiej egzystencji, gdy podstawowe prawa człowieka są zagrożone. Czujność przede wszystkim

26 K. Dębnicki, Whołdzie wielkiej sztuce!, „Film” 1956, 14. s. 3.

27 K. T. Toeplitz, Dziecko i fetysz, czyli humanizm utopijny. (wielki cykl Vittoria De Siki ), „Kwartalnik Filmowy” 1956, 4, s. 14. Toeplitz koncentruje się na omówieniu czterech filmów De Siki: Dzieci ulicy, Złodzieje rowerów, Cud w Mediolanie i Umberto D. Nie wspomina natomiast o wcześniejszym filmie - Dzieci patrza na nas, który został zrealizowany przez De Sikę w 1943 roku (ale nie był w Polsce wyświetlany). 
moralna, wrażliwość przede wszystkim na krzywdę dziejącą się słabym $\mathrm{i}$ bezbronnym jest podstawowym motorem humanizmu utopijnego ${ }^{28}$.

- przekonuje autor. Toeplitz nie przypisuje zatem De Sice komunistycznych poglądów, ale niejako usprawiedliwia go za ich brak:

Obok konsekwentnego programu komunistów, istnieje szereg innych postaw, w których w sposób mniej lub bardziej konsekwentny wyrażają się humanistyczne tęsknoty społeczne, wyraża się bunt przeciw temu co jest i marzenie o tym, co nadejść powinno. Program De Siki jest jednym z najszlachetniejszych przejawów takiej właśnie postawy ${ }^{29}$.

Drugi szkic zatytułowany Humaniści w walce z utopiq autorstwa Zbigniewa Gawraka dowodzi natomiast - w duchu stalinowskim - że twórczość De Siki i Zavattiniego „nie będąc subiektywnie rewolucyjną, a nawet zaangażowaną politycznie, dzięki miłości człowieka i wysunięciu na czoło kryterium sumienia społecznego jest sztuką obiektywnie w wysokim stopniu rewolucyjną, w wysokim stopniu skuteczną rewolucyjnie" ${ }^{30}$.

Świadectwem wyróżniającej się pozycji Złodziei rowerów w opinii polskiej krytyki na tle innych filmów kinematografii światowej pozostają także dwie książki wydane w 1956 roku - Filmy, które pamiętamy Jerzego Płażewskiego oraz Latarnia czarnoksięska Aleksandra Jackiewicza. W publikacji Płażewskiego stanowiącej omówienie - subiektywnie wybranych - 48 dziel, które w jakiś sposób poruszyły jej autora, realizacji De Siki poświęcony został bowiem odrębny, obszerny esej zatytułowany Bez grubego moratu i demaskatorskich monologów ${ }^{31}$. Wedle Płażewskiego Złodzieje rowerów to „arcydzieło i właśnie dlatego wystarcza samo w sobie”. Autor stwierdza nawet: „Recenzent komentujący ten film ośmiesza się... Jeśli istnieje widz tak tępy, że nie pojmuje sensu Złodziei, to do takiego nie trafi nawet najprzejrzystszy komentarz"32. W finale szkicu pada zaś pytanie: czy dzieło De Siki jest pesymistyczne? Od-

28 Ibiddem.

29 Ibidem, s. 37.

30 Z. Gawrak, Humaniści w walce z utopia, „Kwartalnik Filmowy” 1956, 4.

31 Esej dotyczący Złodziei rowerów znajduje się w części III książki (opatrzonej nagłówkiem „Realiści patrzą na świat kapitalizmu”). W części tej znajduje się omówienie 11 filmów, w tym aż 5 włoskich. Prócz Złodziei rowerów odnajdziemy eseje o filmach: Podróż w nieznane, Droga nadziei, Cud w Mediolanie oraz Rzym, godzina 11.

32 J. Płażewski, Filmy, które pamiętamy, Warszawa 1956, s. 172. Płażewski pisze także: „w dowolnym filmie gangsterskim tuzin nagłych śmierci nie robi ani połowy takiego wrażenia, co jedna łza małego Bruno, który kątem oka dostrzega, że jego ojciec ukradt, że biją go za to po głowie, zrzucają kapelusz ...", Ibidem, s. 178. 
powiedź jest następująca: „Prawda, film kończy się po nieudanej kradzieży, bez roweru. Antonio z Brunem wracają do domu. [...] Ich jutro nie jest na pewno radosne. Ale radosne jest to, że dojrzewa protest przeciw krzywdzie. U Antonia i u twórców filmu nie jest pesymistą ten, kto służy życiu"33. Płażewski, podobnie jak Laskowska i Grzelecki, w swojej książce odpiera zatem zarzuty o pesymizm, które były formułowane wobec filmu na początku lat 50 .

W Latarni czarnoksięskiej Jackiewicza Złodzieje rowerów stanowią natomiast swoisty punkt odniesienia - należą do filmowego kanonu. Autor w wielu esejach i przy rozmaitych tematach odwołuje się do poszczególnych scen $\mathrm{z}$ fil$\mathrm{mu}$, bądź przywołuje jego postaci. I tak na przykład w felietonie Bohaterowie filmowi sa wśród nas czytamy:

Dzięki kinu krąg naszych znajomych bardzo się rozszerzył. Należy do niego już dziś Piotr I i włoski bezrobotny, któremu skradziono rower, Szczęsny z Włocławka i utalentowany partyzant młodej rewolucji - Czapajew. [...] Poznaliśmy najskrytsze myśli tych ludzi. Oczami Antonia ze Ztodziei rowerów De Siki - przyglądaliśmy się stojącemu na ulicy bez opieki cudzemu rowerowi, któremu porwanie dałoby mu znów możliwości egzystencji. Sercem Antonia przeżywaliśmy jego rozterkę ${ }^{34}$.

Natomiast w felietonie Sztuka milczenia, pisząc o filmowej zasadzie, wedle której tego, co można pokazać na ekranie, nie należy wypowiadać słowem, Jackiewicz powołuje się na epizody z dzieła De Siki (,Wszyscy pamiętamy [...] nieme sceny pomiędzy Antoniem ze Złodziei rowerów a jego synkiem, ich cichy dramat, ich nieme swary, ich radość przy posiłku") ${ }^{35}$.

Jackiewicz jest także autorem tekstu Rowerowa tragedia zamieszczonego na łamach „Filmu” w 1956 roku $^{36}$. W artykule autor próbuje odpowiedzieć na - jak sam stwierdza - „nierozsądne pytanie, jaki film współczesny ceni najwyżej?”. Wybór badacza pada właśnie na Złodziei rowerów nazwanych „współczesną Odyseją - bardziej prozaiczną, a przez to bardziej tragiczną niż ta starożytna”. Jackiewicz zwraca uwagę na „dramat milczenia rozgrywający się w obrazach" i przyrównuje Antonia do Odyseusza. W domu na bohatera czeka Penelopa, zaś on dryfuje po „czarodziejskich lądach” - „targach starzyzny z lśniącą masą rowerów", z których żaden nie należy do protagonisty. Przywołany artykuł jest głosem istotnym, ponieważ zawiera (pierwszy raz tak wyraźnie

33 Ibidem, s. 181.

34 A. Jackiewicz, Latarnia czarnoksięska, Warszawa 1956, s. 46. W książce znajdują się także liczne fotografie $\mathrm{z}$ filmu.

35 Ibidem, s. 121.

36 A. Jackiewicz, Rowerowa tragedia, „Film” 1956, 37, s. 10 (w cyklu „Jarmark filmów"). 
w odniesieniu do Złodziei rowerów) refleksję na temat metaforycznego wymiaru filmu. Wymiaru, który w latach stalinizmu był całkowicie pomijany; dzieło odczytywano bowiem, o czym wspominałam, wyłącznie w kluczu politycznym.

W tym samym roku na łamach „Filmu” ukazał się artykuł włoskiego korespondenta Libero Solaroliego, w którym autor odpowiada na pytanie „dlaczego kinematografia włoska stworzyła niewiele filmów na poziomie Złodziei rowerów” (historia Antonia jest już zatem swoistym „dziełem modelowym” i wzorem do naśladowania). Solaroli wskazuje na dwa czynniki. Po pierwsze, zwraca uwagę na zdominowanie włoskiej kinematografii (począwszy od zakończenia II wojny światowej) przez filmy zagraniczne, głównie amerykańskie. Po drugie, akcentuje pośredni wpływ kapitału amerykańskiego na produkcję włoską. Ogromne zyski z wyświetlania filmów amerykańskich na ekranach włoskich kin były bowiem wskutek przepisów dewizowych częściowo „zamrażane” we Włoszech i filie wytwórni hollywoodzkich inwestowały ten kapitał w produkcję miejscową, wywierając tym samym wpływ na tematykę realizowanych filmów $^{37}$. Oba spostrzeżenia są oczywiście trafne. Zresztą, ironicznego komentarza do amerykanizacji włoskiej kinematografii możemy dopatrzeć się także w Ztodziejach rowerów (Antonio traci bowiem rower, gdy wiesza plakat Rity Hayworth. Można więc powiedzieć pół żartem, pół serio, że to Hollywood jest przyczyną tragedii bohatera...).

W Polsce Ludowej instytucjonalna recepcja Złodziei rowerów była odpryskiem polityki wewnętrznej. W okresie stalinizmu, w którym film pojawił się na polskich ekranach, oskarżano go o brak rewolucyjnych ideałów i pesymizm. Dopiero począwszy od 1954 roku dzieło De Siki spotyka się z jednoznaczną aprobatą krytyki. W filmie dostrzeżono wówczas potencjal, daleko wykraczający poza doraźną interpretację polityczną. Złodzieje rowerów - realizacja, która we Włoszech od początku uznana została za produkcję wybitną - nad Wisłą dopiero po 1956 roku otrzymała więc niekwestionowany status arcydzieła.

\section{Bibliografia}

Armes R., Patterns of Realism. A Study of Italian Neo-Realist Cinema, London 1971.

Baldini E., Ladri di biciclette e l'America, [w:] Ladri di biciclette. Nuove ricerche e un'antologia della critica (1948-1949), G. De Santi (red.), Laceno 2009.

Beylin K., Doświadczenia, które ucza..., „Film” 1949, 16, s. 15.

Dębnicki K., Whołdzie wielkiej sztuce!, „Film” 1956, 14, s. 3.

Gawrak Z., Humaniści w walce z utopia, „Kwartalnik Filmowy” 1956, 4.

Grzelecki S., Laskowska H., O filmie włoskim, Warszawa 1955.

Jackiewicz A., Latarnia czarnoksięska, Warszawa 1956.

Jackiewicz A., Rowerowa tragedia, „Film” 1956, 37, s. 10.

37 L. Solaroli, Kilka spraw kinematografii włoskiej, „Film” 1956, 14, s. 3. 
Klejsa K., Świat, który przezwyciężamy i pozostawiamy za sobą. Import, rozpowszechnianie $i$ widownia filmowa $z$ krajów kapitalistycznych $w$ Polsce Ludowej w latach 1949-1956 w świetle badań archiwalnych, „Kwartalnik Filmowy” 2019, 108.

K. M., Złodzieje oskarżają swym losem prawdziwych winowajców, „Film” 1951, 4, s. 10.

Martini E. (red.), Gianni Amelio: le regole e il gioco, Bergamo 1999.

Noto P., Pitassio F., Il cinema neorealista, Bologna 2012.

Pasztor M., Jarosz D., Nie tylko Fiat. Z dziejów stosunków polsko-włoskich 1945-1989, Warszawa 2018.

Płażewski J., Robotnik z huty Breda, „Film” 1949, 15, s. 12.

Płażewski J., Filmy, które pamiętamy, Warszawa 1956.

Solaroli L., Kilka spraw kinematografii wtoskiej, „Film” 1956, 14, s. 3.

Toeplitz J., Historia filmu polskiego tom III, Warszawa 1974.

Toeplitz K. T., Komentarz do filmu „Rzym godzina 11”, „Kwartalnik Filmowy” 1954, 2, s. 31.

Toeplitz K. T., Groch o ekran, Warszawa 1955.

Toeplitz K. T., Dziecko ifetysz, czyli humanizm utopijny. (wielki cykl Vittoria De Siki), „Kwartalnik Filmowy" 1956, 4.

Winnington R., Bicycle Thieves, „Sight and Sound”1950, 19, s. 26.

Zajiček E., Poza ekranem. Kinematografia polska 1918-1991, Warszawa 1992.

Zwierzchowski P., Pęknięty monolit, Bydgoszcz 2005. 